\title{
Phylogeography of a deep-sea demersal fish, Bothrocara hollandi, in the Japan Sea
}

\author{
Shigeaki Kojima ${ }^{1, *}$, Ryoko Segawa $^{2}$, Ikuo Hayashi ${ }^{3}$, Muneo Okiyama ${ }^{4, * *}$ \\ ${ }^{1}$ Ocean Research Institute, University of Tokyo, Tokyo 164-8639, Japan \\ ${ }^{2}$ Department of Biology, Faculty of Science, Tokyo Metropolitan University, Tokyo 192-0364, Japan \\ ${ }^{3}$ Japan Sea National Fisheries Research Institute, Niigata 951-8121, Japan \\ ${ }^{4}$ National Science Museum, Tokyo 169-0073, Japan
}

\begin{abstract}
The population structure of Bothrocara hollandi, a dominant deep-sea demersal fish in the Japan Sea, was analyzed on the basis of the nucleotide sequence of part of the mitochondrial control region. The 296 individuals analyzed were collected at 17 sites at depths between 375 and $1677 \mathrm{~m}$, and could be divided into a distinct monophyletic group of haplotypes and a paraphyletic group that contained the remaining haplotypes. Individuals in the first group were collected only from shallower sites at depths less than $1100 \mathrm{~m}$, and they were found predominantly off the western part of Honshu Island (the Japanese mainland). Individuals in the second group were collected from all sites at which fish were sampled. The genetic diversity of the first group was greater than that of the second group. As a consequence, the genetic diversity of populations showed a tendency to decrease with increasing depth. The divergence of the 2 groups was estimated to have occurred during the early part of the last glacial period. The geographical pattern of distribution of haplotypes might be attributable to the accumulation of unique genetic characteristics in different refuges during the last glacial period and to secondary contacts as a result of migration from such refuges after the last glacial period. No genetic differentiation between the 2 morphotypes of this species was detected.
\end{abstract}

KEY WORDS: Phylogeography · Deep-sea demersal fish · Bothrocara hollandi - Japan Sea · Mitochondrial DNA

Resale or republication not permitted without written consent of the publisher

\section{INTRODUCTION}

The Japan Sea is a semi-enclosed marginal sea that is separated from neighboring waters by relatively narrow and shallow straits. It has been proposed that the Japan Sea might have been more isolated from such waters during glacial periods than during interglacial periods (Ohshima 1990, Tada 1994, Tada et al. 1999). In addition, the input of a significant amount of freshwater into the surface layer of the Japan Sea appears to have caused severe anoxic conditions during the last maximum glacial period (20000 to $15000 \mathrm{yr}$ ago), as indi-

\footnotetext{
*E-mail: kojima@ori.u-tokyo.ac.jp

** Present address: Nagasaki 2-10-12, Toshima, Tokyo 1710051, Japan
}

cated by the results of taxonomic and geochemical analyses of microfossil assemblages within core samples of sediment (Tanimura 1981, Oba et al. 1991, Tada 1994, Crusius et al. 1999, Tada et al. 1999, Gorbarenko \& Southon 2000). A major environmental change of this type should have resulted in the fragmentation and reduction of populations of many marine organisms. As a result, we would expect that significant genetic differences between conspecific populations would have accumulated independently both in the Japan Sea and in neighboring areas, and that marine fauna endemic to the Japan Sea would have been established.

Molecular biological techniques, such as the direct sequencing of products of the polymerase chain reaction (PCR) allow the analysis of the geographical structure of intraspecific genetic variations; the general 
term for such analysis is phylogeography (Avise 1994, 2000). The marine fauna of the Japan Sea should provide good material for phylogeographical studies. Indeed, Kojima et al. (1997) analyzed the population structure of a Japanese turban shell, Turbo (Batillus) cornutus, around the Japanese Islands, and demonstrated significant intraspecific genetic differences between specimens on the Pacific coast and those on the coast of the Japan Sea off Honshu Island (the Japanese mainland). Significant genetic differences were also demonstrated between specimens of another gastropod species, Omphalius pfeifferi, from both coasts of Honshu Island (Kojima et al. unpubl. data). Furthermore, allozyme electrophoresis revealed significant genetic differences between populations in the Japan Sea and the northwestern Pacific of an arrow worm, Parasagitta elegans (Thuesen et al. 1993), a sea urchin, Strongylocentrotus nudus, and a sea star, Asterine pectinifera (Matsuoka et al. 1995).

The genetic diversity of populations of deep-sea organisms has attracted the attention of deep-sea biologists for many years. During the 1970s, much research involving allozyme electrophoresis was performed in attempts to reveal the bathymetrical patterns of genetic diversity among populations of marine fauna (Doyle 1972, Goochi \& Schopf 1972, Ayala \& Valentine 1974, Ayala et al. 1975, Valentine \& Ayala 1975). The possible causes of the high genetic diversity that was discovered were discussed for populations of various deep-sea species (Goochi \& Schopf 1972, Ayala et al. 1975, Murphy et al. 1976, Soulé 1976). The analytical power of allozyme electrophoresis is somewhat too low for the quantitative resolution of genetic variations over a geographic range, and the results obtained may be biased by natural selection, which might operate in different ways at different depths. For an accurate understanding of the genetic characteristics of deep-sea fauna, more detailed information about the genetic structure of various organisms that inhabit the deep-sea is indispensable. While analytical methods based on DNA sequences can be expected to contribute to such studies (Chase et al. 1998, Etter et al. 1999), phylogeographical analyses of deep-sea fauna using DNA sequences have been rather limited to date except in the case of fauna in deep-sea reducing environments, such as hydrothermal vents and seep areas (Creasey \& Rogers 1999, Gage \& Young 1999).

Bothrocara hollandi is the dominant deep-sea demersal fish in the Japan Sea, and it is believed to be one of the species that are endemic to the Japan Sea and the Sea of Okhotsk. Although this species was also reported for the Yellow Sea (Nakabo 1993), this report might have been the result of misidentification and there is no clear evidence that it inhabits this sea area (Kinoshita pers. comm.). B. hollandi has been collected from the deepest site examined in the Japan Sea, and is distributed from 200 to $1980 \mathrm{~m}$, covering the broadest range of depths of any demersal fish in the Japan Sea. This species has 2 morphotypes that are distributed above and below a depth of $800 \mathrm{~m}$. A large white type inhabits shallower areas and a small black type inhabits deeper areas (Okiyama unpubl. data). In the present study, we analyzed the genetic structure of populations of $B$. hollandi with reference to changes in genetic diversity with depth in the Japan Sea. The analysis was based on the nucleotide sequences of the first half of the control region, which has the highest evolutionary rate within mitochondrial DNA (Lee et al. 1995). Therefore, the analysis of this region is expected to be useful for detecting genetic differences among intraspecific populations formed through relatively recent events such as severe reduction of habitable areas during the last glacial period.

\section{MATERIALS AND METHODS}

A total of 296 individual specimens of Bothrocara hollandi were collected at 17 sampling stations in the Japan Sea during Cruises KT-96-17, KT97-15 and KT-98-17 of RV 'Tansei-Maru' of the Ocean Research Institute, University of Tokyo (Fig. 1, Table 1). A single specimen of a congeneric species, B. tanakae, which was used as an outgroup for phylogenetic analysis, was collected in the north Western Pacific off Northeastern Japan $\left(39^{\circ} 24.39^{\prime} \mathrm{N}, 142^{\circ} 51.55^{\prime} \mathrm{E}_{\text {; }}\right.$ depth

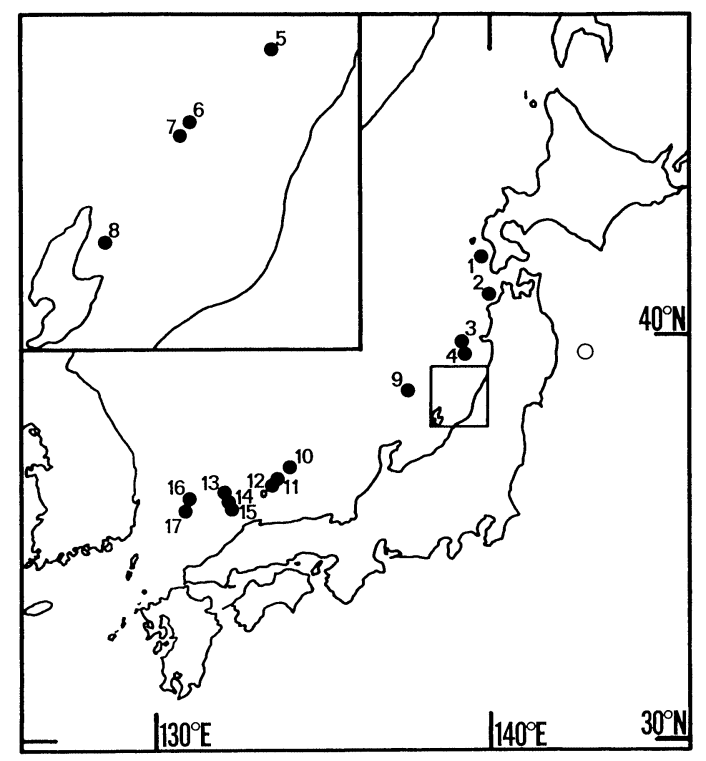

Fig. 1. Locations of stations at which Bothrocara hollandi was collected $(\bullet)$; details in Table 1. (o) Station at which congener $B$. tanakae was collected. Inset: enlarged view of area within square in main map 
Table 1. List of sampling stations. Station numbers correspond to those in Fig. 1

\begin{tabular}{|lcrcc|}
\hline \multirow{2}{*}{ Stn } & Position & Depth (m) & Cruise & N \\
\hline 1 & $41^{\circ} 38.62^{\prime} \mathrm{N}, 139^{\circ} 44.89^{\prime} \mathrm{E}$ & 1438 & KT96-17 & 15 \\
2 & $40^{\circ} 58.95^{\prime} \mathrm{N}, 139^{\circ} 53.99^{\prime} \mathrm{E}$ & 816 & KT97-15 & 17 \\
3 & $39^{\circ} 53.43^{\prime} \mathrm{N}, 139^{\circ} 04.72^{\prime} \mathrm{E}$ & 1474 & KT96-17 & 24 \\
4 & $39^{\circ} 41.05^{\prime} \mathrm{N}, 139^{\circ} 09.28^{\prime} \mathrm{E}$ & 1065 & KT96-17 & 24 \\
5 & $38^{\circ} 57.01^{\prime} \mathrm{N}, 139^{\circ} 25.05^{\prime} \mathrm{E}$ & 542 & KT97-15 & 14 \\
6 & $38^{\circ} 40.20^{\prime} \mathrm{N}, 139^{\circ} 01.01^{\prime} \mathrm{E}$ & 594 & KT97-15 & 20 \\
7 & $38^{\circ} 37.00^{\prime} \mathrm{N}, 138^{\circ} 58.18^{\prime} \mathrm{E}$ & 600 & KT96-17 & 15 \\
8 & $38^{\circ} 12.24^{\prime} \mathrm{N}, 138^{\circ} 35.69^{\prime} \mathrm{E}$ & 637 & KT97-15 & 20 \\
9 & $38^{\circ} 42.51^{\prime} \mathrm{N}, 137^{\circ} 50.84^{\prime} \mathrm{E}$ & 1677 & KT97-15 & 15 \\
10 & $36^{\circ} 54.03^{\prime} \mathrm{N}, 133^{\circ} 51.32^{\prime} \mathrm{E}$ & 1544 & KT96-17 & 10 \\
11 & $36^{\circ} 43.37^{\prime} \mathrm{N}, 133^{\circ} 37.56^{\prime} \mathrm{E}$ & 1164 & KT96-17 & 23 \\
12 & $36^{\circ} 38.63^{\prime} \mathrm{N}, 133^{\circ} 27.41^{\prime} \mathrm{E}$ & 509 & KT96-17 & 14 \\
13 & $36^{\circ} 19.60^{\prime} \mathrm{N}, 132^{\circ} 05.09^{\prime} \mathrm{E}$ & 1561 & KT96-17 & 20 \\
14 & $35^{\circ} 53.31^{\prime} \mathrm{N}, 132^{\circ} 14.44^{\prime} \mathrm{E}$ & 519 & KT98-17 & 20 \\
15 & $35^{\circ} 50.97^{\prime} \mathrm{N}, 132^{\circ} 15.22^{\prime} \mathrm{E}$ & 401 & KT98-17 & 20 \\
16 & $35^{\circ} 55.00^{\prime} \mathrm{N}, 131^{\circ} 11.11^{\prime} \mathrm{E}$ & 1076 & KT98-17 & 15 \\
17 & $35^{\circ} 47.72^{\prime} \mathrm{N}, 131^{\circ} 09.07^{\prime} \mathrm{E}$ & 375 & KT98-17 & 10 \\
& & & & \\
\hline
\end{tabular}

$1654 \mathrm{~m}$ ) during Cruise KT-96-16 of RV 'Tansei-Maru' (open circle in Fig. 1). All samples were collected by a beam trawl with a $3 \mathrm{~m}$ span, and were kept in a freezer $\left(-20^{\circ} \mathrm{C}\right)$ prior to analysis.

A small piece (about $0.1 \mathrm{~cm}^{3}$ ) of muscle tissue from each fish was minced in $500 \mu \mathrm{l}$ of a solution of $100 \mathrm{mM}$ EDTA, 50 mM Tris (pH 8.0), 1 \% sodium dodecyl sulfate (SDS), and $100 \mu \mathrm{g} \mathrm{ml}^{-1}$ proteinase $\mathrm{K}$ and incubated at $50^{\circ} \mathrm{C}$ overnight. Each homogenate was extracted with buffer-equilibrated phenol, and DNA was precipitated with 2.5 volumes of cold ethanol, rinsed with $70 \%$ ethanol, dried and resuspended in $50 \mu \mathrm{l}$ of double-distilled water (DDW).

Using $1 \mu$ l of each sample of DNA, we amplified the control region of the mitochondrial DNA by the polymerase chain reaction (PCR) using the primers Pro-L, 5'-CTACCTCCAACTCCCAAAGC-3', and 1612SAR-H, 5'-ATAGTGGGGTATCTAATCCCAGTT-3' (Palumbi et al. 1991), and rTaq DNA polymerase (Toyobo, Inc., Tokyo, Japan). The parameters for amplification were $94^{\circ} \mathrm{C}$ for $1 \mathrm{~min}$ and then 30 cycles of $92^{\circ} \mathrm{C}$ for $40 \mathrm{~s}, 55^{\circ} \mathrm{C}$ for $60 \mathrm{~s}$ and $72^{\circ} \mathrm{C}$ for $90 \mathrm{~s}$. GeneReleaser $^{\mathrm{TM}}$ (BioVenture, Inc., Murfreeboro, Tennessee, USA) was used to sequester products of cell lysis that might have inhibited the polymerase.

The nucleotide sequence of the first half of the control region was determined by the dideoxynucleotide chain- termination method with a Sequenase ${ }^{\mathrm{TM}}$ PCR productsequencing kit (United States Biochemical Corp., Cleveland, Ohio, USA) with primers Pro-L, CR-1 (5'CCACYGGTTAWGATATACG-3') and/or CR-2 (5'CRAATACTTGTCCCTCACCCTC-3'). The primers CR-1 and CR-2 were synthesized on the basis of determined sequences, and their positions are shown in Fig. 2.

We constructed a phylogenetic tree by the maximum parsimony method using the heuristic search approach of the computer program 'Parsimony', which was kindly provided by Dr K. Tamura of Tokyo Metropolitan University. The genetic diversity of each population was estimated by 2 indices, namely, gene diversity, i.e. the probability that 2 randomly chosen haplotypes are different (Nei 1987), and nucleotide diversity, which is expressed by the probability that 2 randomly chosen homologous nucleotides are different (Tajima 1983, Nei 1987). Genetic distance between haplotypes was calculated by the method of Tajima \& Nei (1984). The significance of population structure and genetic differentiation between morphotypes were tested by the analysis of molecular variance (AMOVA) using a permutational approach (Excoffier et al. 1992). We performed the analysis with the computer program package 'Arlequin' (Schnider et al. 1996).

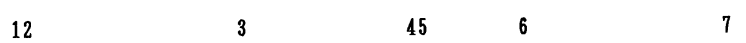
Bh TAATTATATCATATCATGTATTT-AATACATATATGTATATACACCATTAATTTATTTTAACCATTTTAATGGTTATCTAGGACATATA

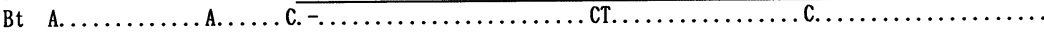

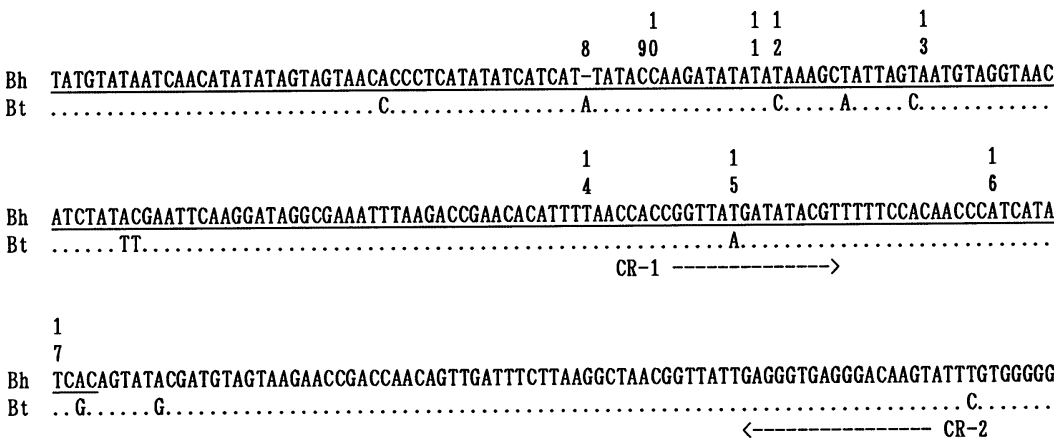

Bh GTTTCACAGAGTGCACTATTCCTGGCATTTGGTTCCGCAGTCAGGGCCATAAGCCCGCTTGACTCCCTGCACTTTCATCGACGCTTACA

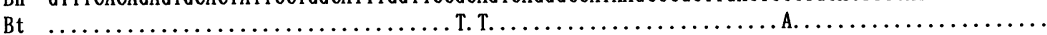

Bh TAGATTAATGGTGGAGTGCATAAGCGAGATAACCCAGTATGCCGGGCGTTCTCGCACGGGTGCAAGGGGTTTCTCTTTTTTT

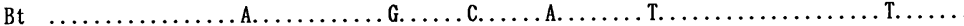

Fig. 2. Bothrocara hollandi (Bh) B. tanakae (Bt). Nucleotide sequence of part of the mitochondrial control region of the dominant haplotype (No. 1 in Table 2). Dots indicate nucleotides that are identical in both sequences. Sequence of the underlined region was determined for all specimens. -: site at which a nucleotide deletion was detected; numbers: polymorphic sites within sequences from specimens of $B$. hollandi. Positions of primers CR-1 and CR-2 are indicated. The nucleotide sequences will appear in the GSDB, DDBJ, EMBL and NCBI nucleotide sequence databases under Accession Nos. AB056505 (Bh) and AB056506 (Bt) 


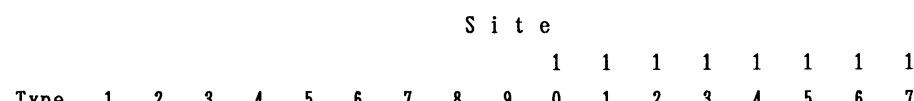

$\begin{array}{cccccccccccccccccc}\text { Type } & 1 & 2 & 3 & 4 & 5 & 6 & 7 & 8 & 9 & 0 & 1 & 2 & 3 & 4 & 5 & 6 & 7 \\ 1 & \text { T } & - & \text { C } & \text { T } & \text { T } & \text { T } & \text { T } & - & \text { C } & \text { C } & \text { T } & \text { T } & \text { A } & \text { T } & \text { T } & \text { A } & \text { T }\end{array}$

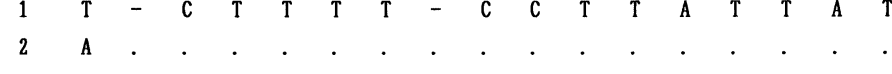

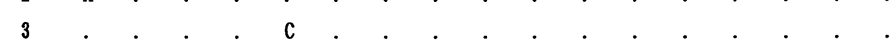

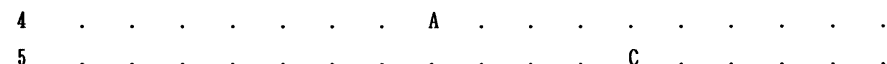

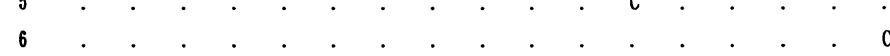

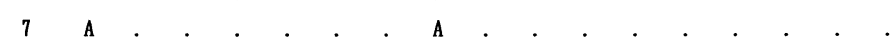

8 A . . . . . . . . . . . . . . . C

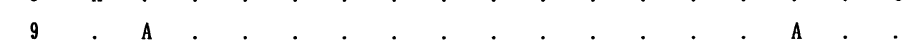

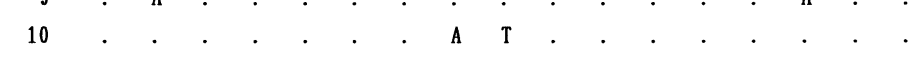

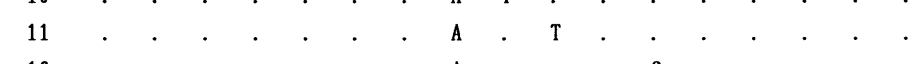

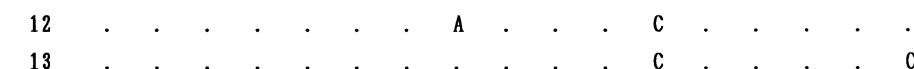

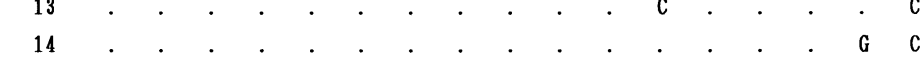

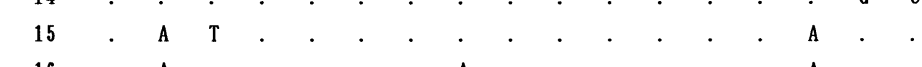

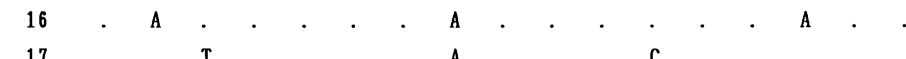

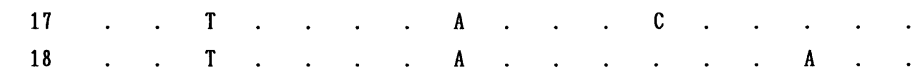

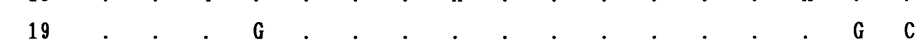

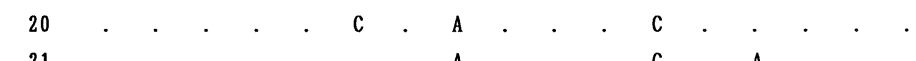

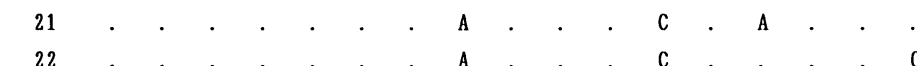

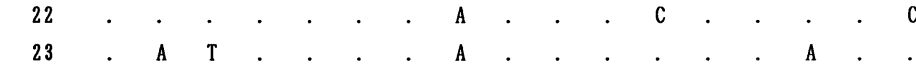

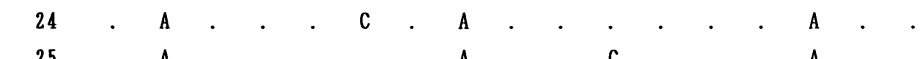

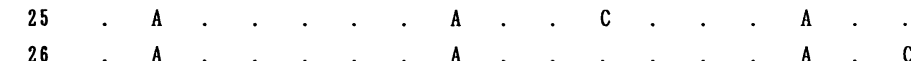

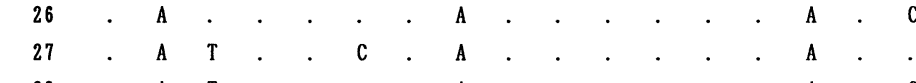

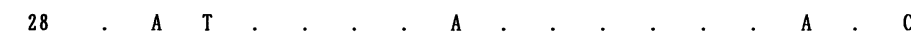

$29 \cdot \mathrm{A} \cdot \mathrm{A} \cdot \mathrm{C} \cdot \mathrm{A} \cdot \mathrm{A} \cdot \mathrm{A} \cdot \mathrm{T}$ A .

30 . A . . . . C A A . C C . . A . A .

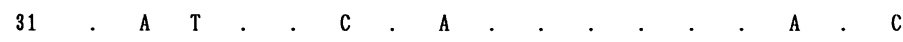

32 . A T . . C . A . . . . . . A G C

Fig. 3. Bothrocara hollandi. Nucleotides at polymorphic sites in part of the mitochondrial control region. Numbers of sites refer to positions shown in Fig. 2. Dots indicate nucleotides that are identical to those in the top line

\section{RESULTS}

The nucleotide sequence of the first half of mitochondrial control region (about 530 base pairs) of the dominant haplotype of Bothrocara hollandi is shown in Fig. 2. Only 1 polymorphic site was detected within the posterior part (that lacking underlining in Fig. 2) when the sequences of 18 individuals were compared. Thus, the anterior part, which was about 240 base pairs in length (underlined in Fig. 2), was sequenced for all remaining specimens. When we examined this region from all 296 samples, we found that 17 sites were polymorphic (Fig. 2). There were 2 nucleotide deletions/ insertions and 15 nucleotide substitutions. The 296 individuals had a total of 32 haplotypes, as shown in Fig. 3. Two individuals exhibited heteroplasmy. One was collected at Stn 11 and had Mitochondrial Types 1 and 2; the other was collected at Stn 17 and had Mitochondrial Types 23 and 28 (Table 2).

Fig. 4 shows the phylogenetic relationships among the resultant haplotypes. Fourteen haplotypes (Nos. 9, 15, 16, 18 and 23 though 32) formed the most derivative cluster. All the maximum parsimonious trees supported the monophyly of this cluster. This group and the group that included all the remaining haplotypes are hereinafter referred to as Group A and Group B, respectively.

Individuals in Group B had been collected from all sampling stations while those in Group A had been collected from stations at depths $<1100 \mathrm{~m}$ (Table 2, Fig. 5). In addition, individuals in Group A were distributed predominantly off the western part of Honshu Island and their easternmost occurrence was at a depth of $600 \mathrm{~m}$ at Stn 7, off Awa-shima Island, Niigata Prefecture (Table 2, Fig. 5). At Stn 6, approximately $8 \mathrm{~km}$ northeast of Stn 7 (Fig. 1), at a depth of $594 \mathrm{~m}$, no individuals belonging to Group A were collected (Fig. 5). The genetic diversity of all individuals in Group B was lower than that of individuals in Group A (Table 3).

Genetic differentiation between the 2 morphotypes of Bothrocara hollandi was tested for 3

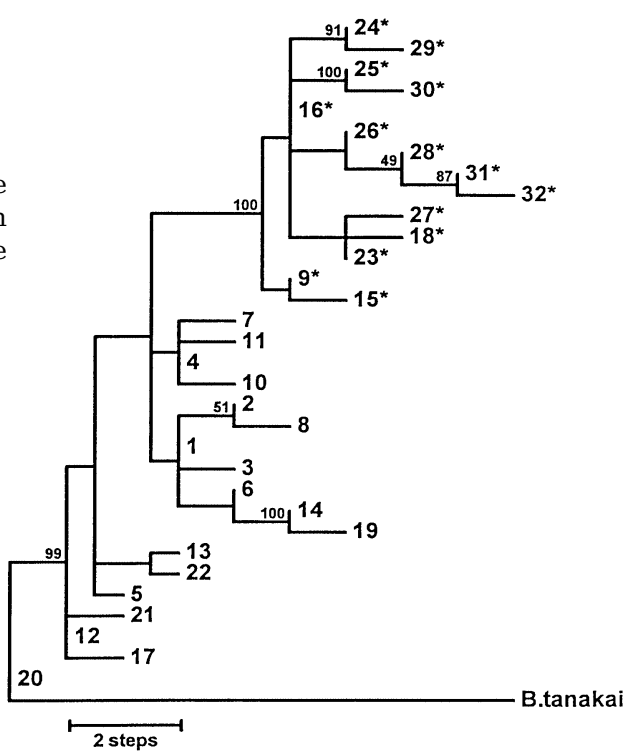

Fig. 4. Bothrocara hollandi. 50\% majority rule consensus phylogram of 42 steps, showing results of the maximum parsimony analysis of haplotypes of $B$. hollandi, with $B$. tanakae as the outgroup (CI [Consistency Index] 0.385; RI [Retention Index] 0.771). Consensus values of more than $50 \%$ are shown above branches. Asterisks indicate hap-lotypes in Group A 
Table 2. Bothrocara hollandi. Haplotype $(\mathrm{H})$ composition of each population. Sampling stations arranged in order of increasing depth. ${ }^{*}$ Haplotypes of Group A

\begin{tabular}{|c|c|c|c|c|c|c|c|c|c|c|c|c|c|c|c|c|c|c|}
\hline $\mathrm{H}$ & 9 & 13 & 10 & 3 & 1 & 11 & 16 & 4 & $\begin{array}{c}\text { Stn } \\
2\end{array}$ & 8 & 7 & 6 & 5 & 14 & 12 & 15 & 17 & Total \\
\hline 1 & 9 & 15 & 7 & 13 & 8 & $16^{a}$ & 9 & 14 & 10 & 4 & 6 & 9 & 6 & 5 & 1 & 0 & 2 & $134^{\mathrm{a}}$ \\
\hline 2 & 0 & 0 & 0 & 0 & 0 & $1^{a}$ & 0 & 0 & 0 & 0 & 0 & 0 & 0 & 0 & 0 & 0 & 0 & $1^{\mathrm{a}}$ \\
\hline 3 & 2 & 0 & 0 & 0 & 1 & 1 & 0 & 0 & 0 & 0 & 0 & 0 & 0 & 0 & 0 & 0 & 0 & 4 \\
\hline 4 & 2 & 1 & 1 & 4 & 1 & 4 & 1 & 5 & 3 & 2 & 2 & 4 & 1 & 3 & 1 & 0 & 1 & 36 \\
\hline 5 & 0 & 1 & 0 & 1 & 0 & 1 & 0 & 0 & 0 & 0 & 0 & 0 & 1 & 0 & 0 & 0 & 0 & 4 \\
\hline 6 & 0 & 1 & 0 & 0 & 2 & 0 & 0 & 1 & 0 & 0 & 0 & 0 & 0 & 0 & 0 & 0 & 0 & 4 \\
\hline 7 & 0 & 0 & 0 & 0 & 0 & 0 & 0 & 0 & 0 & 0 & 1 & 0 & 0 & 0 & 0 & 0 & 0 & 1 \\
\hline 8 & 0 & 0 & 0 & 0 & 0 & 0 & 0 & 0 & 0 & 1 & 0 & 0 & 0 & 0 & 0 & 0 & 0 & 1 \\
\hline $9^{*}$ & 0 & 0 & 0 & 0 & 0 & 0 & 0 & 0 & 0 & 0 & 0 & 0 & 0 & 0 & 0 & 1 & 0 & 1 \\
\hline 10 & 0 & 1 & 0 & 1 & 0 & 0 & 1 & 0 & 1 & 0 & 0 & 1 & 0 & 0 & 0 & 0 & 0 & 5 \\
\hline 11 & 0 & 0 & 0 & 0 & 0 & 0 & 0 & 0 & 1 & 0 & 0 & 0 & 0 & 0 & 0 & 0 & 0 & 1 \\
\hline 12 & 1 & 0 & 0 & 3 & 2 & 0 & 1 & 3 & 2 & 7 & 3 & 5 & 4 & 5 & 2 & 6 & 0 & 44 \\
\hline 13 & 0 & 0 & 0 & 0 & 0 & 1 & 0 & 0 & 0 & 0 & 0 & 0 & 0 & 0 & 0 & 0 & 0 & 1 \\
\hline 14 & 0 & 0 & 1 & 0 & 0 & 0 & 0 & 0 & 0 & 0 & 1 & 0 & 0 & 0 & 0 & 0 & 0 & 2 \\
\hline $15^{*}$ & 0 & 0 & 0 & 0 & 0 & 0 & 0 & 0 & 0 & 0 & 0 & 0 & 0 & 2 & 0 & 0 & 0 & 2 \\
\hline $16^{*}$ & 0 & 0 & 0 & 0 & 0 & 0 & 1 & 0 & 0 & 1 & 0 & 0 & 0 & 2 & 1 & 3 & 1 & 9 \\
\hline 17 & 0 & 0 & 0 & 0 & 0 & 0 & 0 & 0 & 0 & 0 & 0 & 0 & 0 & 0 & 0 & 1 & 0 & 1 \\
\hline $18^{*}$ & 0 & 0 & 0 & 0 & 0 & 0 & 0 & 0 & 0 & 0 & 0 & 0 & 0 & 2 & 0 & 0 & 0 & 2 \\
\hline 19 & 0 & 0 & 0 & 0 & 0 & 0 & 0 & 0 & 0 & 0 & 0 & 0 & 1 & 0 & 0 & 0 & 0 & 1 \\
\hline 20 & 0 & 0 & 0 & 0 & 0 & 0 & 0 & 0 & 0 & 0 & 0 & 0 & 1 & 0 & 0 & 0 & 0 & 1 \\
\hline 21 & 1 & 1 & 1 & 2 & 1 & 0 & 0 & 1 & 0 & 0 & 0 & 1 & 0 & 0 & 0 & 0 & 0 & 8 \\
\hline 22 & 0 & 0 & 0 & 0 & 0 & 0 & 0 & 0 & 0 & 1 & 0 & 0 & 0 & 0 & 0 & 0 & 0 & 1 \\
\hline $23^{*}$ & 0 & 0 & 0 & 0 & 0 & 0 & 1 & 0 & 0 & 2 & 1 & 0 & 0 & 1 & 3 & 4 & $5^{\mathrm{a}}$ & $17^{\mathrm{a}}$ \\
\hline $24^{*}$ & 0 & 0 & 0 & 0 & 0 & 0 & 0 & 0 & 0 & 0 & 0 & 0 & 0 & 0 & 1 & 0 & 0 & 1 \\
\hline $25^{*}$ & 0 & 0 & 0 & 0 & 0 & 0 & 0 & 0 & 0 & 0 & 0 & 0 & 0 & 0 & 0 & 2 & 0 & 2 \\
\hline $26^{*}$ & 0 & 0 & 0 & 0 & 0 & 0 & 0 & 0 & 0 & 0 & 0 & 0 & 0 & 0 & 1 & 0 & 0 & 1 \\
\hline $27^{*}$ & 0 & 0 & 0 & 0 & 0 & 0 & 0 & 0 & 0 & 1 & 0 & 0 & 0 & 0 & 1 & 0 & 0 & 2 \\
\hline $28^{*}$ & 0 & 0 & 0 & 0 & 0 & 0 & 0 & 0 & 0 & 0 & 0 & 0 & 0 & 0 & 1 & 2 & $1^{\mathrm{a}}$ & $4^{\mathrm{a}}$ \\
\hline $29^{*}$ & 0 & 0 & 0 & 0 & 0 & 0 & 0 & 0 & 0 & 0 & 1 & 0 & 0 & 0 & 1 & 0 & 0 & 2 \\
\hline $30^{*}$ & 0 & 0 & 0 & 0 & 0 & 0 & 0 & 0 & 0 & 1 & 0 & 0 & 0 & 0 & 0 & 0 & 0 & 1 \\
\hline $31^{*}$ & 0 & 0 & 0 & 0 & 0 & 0 & 1 & 0 & 0 & 0 & 0 & 0 & 0 & 0 & 1 & 0 & 1 & 3 \\
\hline $32^{*}$ & 0 & 0 & 0 & 0 & 0 & 0 & 0 & 0 & 0 & 0 & 0 & 0 & 0 & 0 & 0 & 1 & 0 & 1 \\
\hline
\end{tabular}

transects along which samples from each station were composed of a single morphotype (Table 4). For all 3 transects, no genetic differentiation between the 2 morphotypes was detected (AMOVA, p > 0.05). Genetic structures were also compared among the 3 sea areas (Table 5): off Hokkaido Island (Stns 1 and 2), off northern Honshu Island (Stns 3 to 9), and off western Honshu Island (Stns 10 to 17); and among 4 depth ranges (Table 6): <500 $\mathrm{m}$ (Stns 15 and 17), 500 to $1000 \mathrm{~m}$ (Stns 2, 5, 6, 7, 8, 12 and 14), 1000 to $1500 \mathrm{~m}$ (Stns 1, 3, 4, 11 and 16) and >1500 m (Stns 9, 10 and 13). Although no genetic differentiation was detected among sea areas (AMOVA, p > 0.05), a clear genetic structure was evident along the depth gradient (AMOVA, p < 0.01).

Fig. 6 shows the relationships between the genetic diversity of the population and the sampling depth for Bothrocara hollandi. Genetic diversity decreased significantly with increasing depth for all individuals sampled $(\mathrm{p}<0.001)$ as well as for those in Group B alone $(\mathrm{p}<0.05)$.

\section{DISCUSSION}

Our phylogeographical study of the dominant deepsea demersal fish Bothrocara hollandi in the Japan Sea revealed a clear genetic structure. On the basis of the nucleotide sequences of part of the mitochondrial control region of 296 individuals collected from 17

Table 3. Bothrocara hollandi. Genetic diversity of the 2 groups

\begin{tabular}{|lcc|}
\hline Diversity index & Group A & Group B \\
\hline Gene diversity & $0.85 \pm 0.04$ & $0.66 \pm 0.03$ \\
Nucleotide diversity & $0.00552 \pm 0.00385$ & $0.00265 \pm 0.00227$ \\
\hline
\end{tabular}


Table 4. Bothrocara hollandi. Result of analysis of molecular variance (AMOVA) for genetic differentiation between morphotypes collected from stations on 3 transects. p: probability of having a more extreme variance component and $\phi$-statistic than observed values by chance alone (1000 permutations)

\begin{tabular}{|c|c|c|c|c|c|c|c|}
\hline Transect & $\begin{array}{l}\text { Sampling sta } \\
\text { black type }\end{array}$ & $\begin{array}{l}\text { tions with } \\
\text { white type }\end{array}$ & Variance components & Variance & $\%$ of var. & $\phi$-stat. & $\mathrm{p}$ \\
\hline I & 3,4 & 5 & $\begin{array}{l}\text { Among morphotypes } \\
\text { Among populations within morphotypes } \\
\text { Within populations }\end{array}$ & $\begin{array}{r}0.026 \\
-0.008 \\
0.339\end{array}$ & $\begin{array}{r}7.29 \\
-2.22 \\
94.94\end{array}$ & $\begin{array}{r}0.073 \\
0.051 \\
-0.024\end{array}$ & $\begin{array}{l}0.316 \\
0.541 \\
0.227\end{array}$ \\
\hline II & 10,11 & 12 & $\begin{array}{l}\text { Among morphotypes } \\
\text { Among populations within morphotypes } \\
\text { Within populations }\end{array}$ & $\begin{array}{r}0.408 \\
-0.023 \\
0.496\end{array}$ & $\begin{array}{l}46.30 \\
-2.59 \\
56.29\end{array}$ & $\begin{array}{r}0.463 \\
0.437 \\
-0.048\end{array}$ & $\begin{array}{r}0.316 \\
0.669 \\
<0.001\end{array}$ \\
\hline III & 13 & 14,15 & $\begin{array}{l}\text { Among morphotypes } \\
\text { Among populations within morphotypes } \\
\text { Within populations }\end{array}$ & $\begin{array}{l}0.145 \\
0.049 \\
0.657\end{array}$ & $\begin{array}{r}17.08 \\
5.74 \\
77.17\end{array}$ & $\begin{array}{l}0.171 \\
0.228 \\
0.069\end{array}$ & $\begin{array}{r}0.326 \\
0.117 \\
<0.001\end{array}$ \\
\hline
\end{tabular}

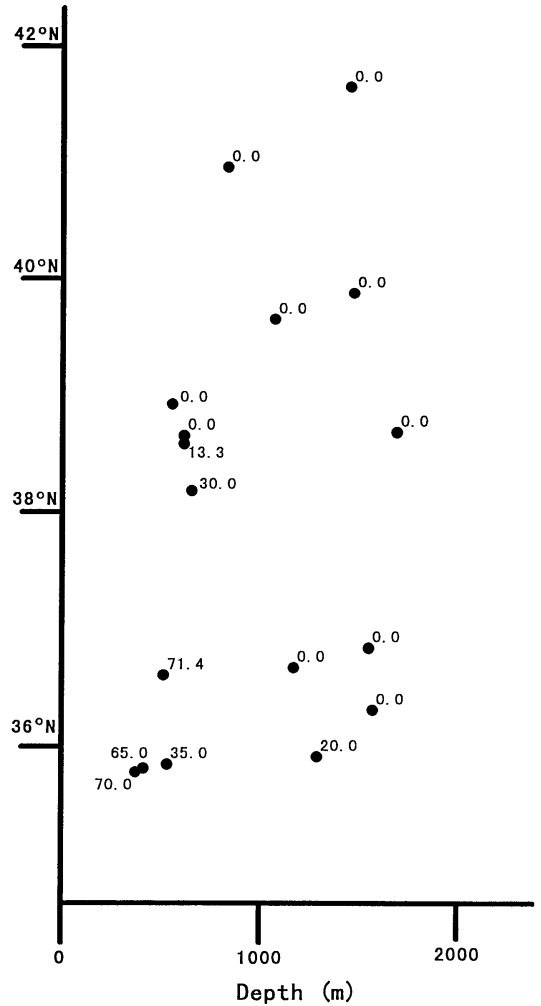

Fig. 5. Bothrocara hollandi. Distribution of the members of 2 groups of haplotypes (Group A and Group B). Geographical position (latitude) at each sampling station is plotted against depth, with the proportion (\%) of Group A individuals in all the samples obtained at each station indicated beside each data point

sites between depths of 375 and $1677 \mathrm{~m}$, we were able to separate the collected specimens into 2 genetically distinct groups, namely a clearly monophyletic group (Group A) and a paraphyletic group that included the remaining haplotypes (Group B). The distribution of individuals in Group A was limited to the coastal area with depths shallower than $1100 \mathrm{~m}$ in
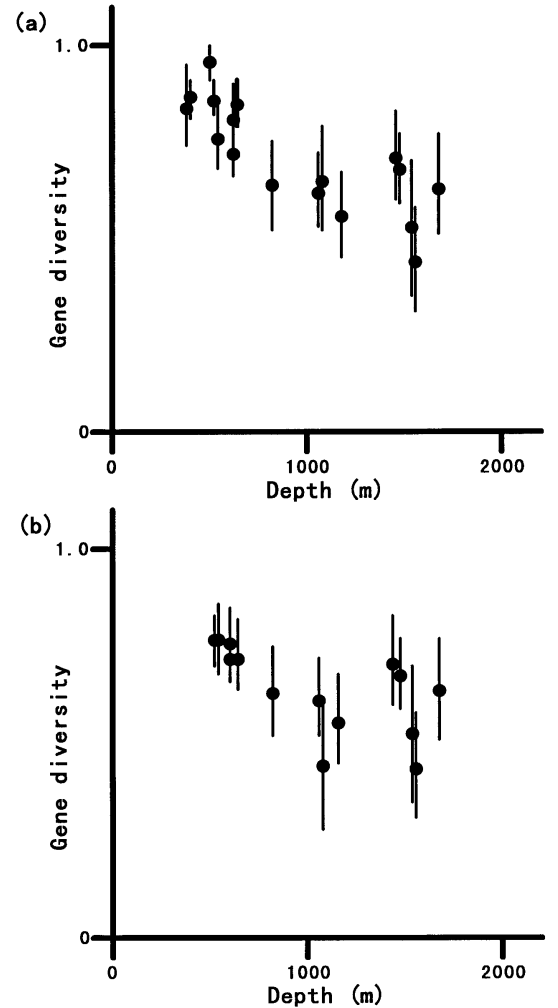

Fig. 6. Bothrocara hollandi. Relationships (means \pm 1 SD) between depth and gene diversity at each sampling station based on individuals in both A and B groups (a) and on individuals in Group B only (b). Only statiFons for which data were available for $>10$ individuals were used to generate these plots

the western part of the Japan Sea, while members of Group B were collected at all sampling sites (Fig. 5). In addition, the genetic diversity of individuals in Group B was lower than that of individuals in Group A (Table 3).

During the last maximum glacial period, the Japan Sea may have been an unsuitable habitat for marine 
organisms because of severe anoxic conditions (Tanimura 1981, Oba et al. 1991, Tada 1994, Crusius et al. 1999, Tada et al. 1999, Gorbarenko \& Southon 2000). Bothrocara hollandi might have survived this period by taking refuge at suitable sites in the Japan Sea and/or adjacent sea areas. The accumulation of unique genetic characteristics at these sites and subsequent secondary contact upon migration to the present habitats might have led to the present geographical pattern of distribution of haplotypes. The paraphyly of haplotypes of Group B, with exclusion of the haplotypes of Group A (Fig. 4), suggests that members of Group A might be derived from a relatively small population of immigrants from the common ancestral population of both groups.

Using the method proposed by Jukes \& Cantor (1969), we calculated the genetic difference between the dominant haplotype in Group A (No. 23) and that in Group B (No. 1) to be 0.0081 . Accepting the rate of evolution of the mitochondrial control region of fishes as 0.12 per million years (Brown et al. 1993, Bremer et al. 1995, Chenoweth et al. 1998), we estimate that the divergence between these 2 groups occurred about 34000 yr ago, at a time corresponding to the early part of the last glacial period.

Specimens of Bothrocara hollandi in Group A were found predominantly in a shallower and more westerly part of the range of distribution of this fish than those in Group B. The highest relative frequency of Group A (71.4\%) was observed at Station 17, which was situated in the westernmost part of the Japan Sea (Fig.1). The present distributional trend of Group A might be explained by the hypothesis that its ancestral population lived, isolated from Group B, in refuges located in a relatively shallow region in the westernmost part of the Japan Sea during the last glacial period, and that Group A is now expanding its distribution. Gorbarenko \& Southon (2000) showed that the sea area on the western shelf of the Tsushima Strait did not become anoxic during the last glacial period, probably because of constant inflow of fresh seawater through the Tsushima Strait. This fact supports our above hypothesis. It is plausible to speculate that, while the severe environment of other areas of the Japan Sea during the last glacial period might have reduced the genetic diversity of the population in Group B, the high genetic diversity of Group A might have been maintained under the relatively moderate environmental conditions of its refuges.

We detected no genetic differentiation between the 2 morphotypes of Bothrocara hollandi (Table 4), and some dominant haplotypes were shared by both morphotypes. Phylogenetic analysis based on the nucleotide sequence of a mitochondrial gene for $16 \mathrm{~S}$ ribosomal RNA also failed to reveal any genetic difference between the morphotypes (Yamaguchi pers. comm.). The morphological differences between the 2 morphotypes could be the results of local factors that govern the growth and coloration of the fish, such as food availability and predation.

The genetic structure of the population of Bothrocara hollandi appears to be determined by depth rather than geographical distance (Tables 5 \& 6). We also found a significant decrease in the genetic diversity of populations of $B$. hollandi with increasing depth (Fig. 6a). This decrease was not so clear in Group B; the individuals of Group A, more genetically diverse than Group B, decreased in occurrence with increasing depth. This indicates that the bathymetric trend in the genetic diversity of the population mainly resulted from the individuals in Group A.

Although genetic differentiation between Groups A and $B$ is relatively small and they are not reciprocally monophyletic (Fig. 4), the possibility that they have already reproductively isolated from each other still remains. If they represent sibling species, the discordance between grouping based on mitochondrial haplotypes and that based on morphotypes could also be attributable to hybridization between the 2 sibling spe- 
cies. Analyses using neutral genetic markers coded in the nuclear DNA will greatly help in revealing the exact taxonomic relationship between the 2 groups.

The effects of changes in the marine environment can be expected to persist in the genetic structure of populations of marine organisms over a long period of time. Thus, it is possible to obtain information about the history of variations in the marine environment from the phylogeography of marine species (Avise 1992, Magoulas et al. 1996, Kojima et al. 2000). In order to evaluate more accurately the relative importance of paleoceanographic effects on the formation of the genetic structure of populations, comparative studies of various aspects of the life history, such as modes of development and feeding strategies, of many marine species are necessary. Marine organisms in the Japan Sea are ideal subjects for such phylogeographic studies because of the dramatic environmental changes that have occurred in the Japan Sea on the millennial timescale over the past 200000 yr (Tada et al. 1999). We have started phylogeographic studies of some marine species, such as intertidal gastropods, starfishes, barnacles and deep-sea brittle stars, in both the Japan Sea and adjacent sea areas. Analysis of a variety of marine species, based on samples collected from waters not only around the Japanese Islands but also off Russia, China and Korea, should provide more detailed information that will help us to understand the genetic diversification of marine organisms associated with environmental variations in the Japan Sea.

Acknowledgements. The authors thank Drs T. Minami and T. Kinoshita for information about the geographical distribution of Bothrocara hollandi. They also thank Mr H. Yieh, Captain $\mathrm{S}$. Hayashikawa and the officers and crew of RV 'TanseiMaru' (Ocean Research Institute, University of Tokyo), as well as the scientists on board, during 4 cruises, for their help in sampling. Dr K. Tamura kindly provided the computer program 'Parsimony'. Part of this study was supported by grants from the Ministry of Education, Science, Sports and Culture of Japan (No. 10836007 and 12NP0201).

\section{LITERATURE CITED}

Avise JC (1992) Molecular population structure and the biogeographic history of regional fauna: a case study with lessons for conservation biology. Oikos 63:62-76

Avise JC (1994) Molecular markers, natural history and evolution. Chapman \& Hall, New York

Avise JC (2000) Phylogeography, the history and formation of species. Harvard University Press, Cambridge

Ayala FJ, Valentine JW (1974) Genetic variability of the cosmopolitan deep-sea ophiuran Ophiomusium lamani. Mar Biol 27:51-57

Ayala FJ, Valentine JW, Hedgecock D, Barr LG (1975) Deepsea asteroids: high genetic variability in a stable environment. Evolution 29:203-212

Bremer JRA, Baker AJ, Mejuto J (1995) Mitochondrial DNA control region sequences indicate extensive mixing of swordfish (Xiphias gladius) populations in the Atlantic Ocean. Can J Fish Aquat Sci 52:1720-1732

Brown JR, Beckenbach AT, Smith MJ (1993) Intraspecific DNA sequence variation of the mitochondrial control region of white sturgeon (Acipenser transmontanus). Mol Biol Evol 10:326-341

Chase MR, Etter RJ, Rex MA, Quattro JM (1998) Bathymetric patterns of genetic variation in a deep-sea protobranch bivalve, Deminucla atacellana. Mar Biol 131:301-308

Chenoweth SF, Hughes JM, Keenan CP, Lavery S (1998) When oceans meet: a teleost shows secondary intergradation at an Indian-Pacific interface. Proc R Soc Lond Ser Biol Sci 265:415-420

Creasey SS, Rogers AD (1999) Population genetics of bathyal and abyssal organisms. Adv Mar Biol 35:1-151

Crusius J, Pedersen TF, Calvert SE, Cowie GL, Oba T (1999) A 36 kyr geographical record from the Sea of Japan of organic matter flux variations and changes in intermediate water oxygen concentration. Paleoceanography 14: $248-259$

Doyle RW (1972) Genetic variation in Ophiomusium lymani (Echinodermata) populations in the deep sea. Deep-Sea Res 19:661-664

Etter RJ, Rex MA, Chase MC, Quattro JM (1999) A genetic dimension to deep-sea biodiversity. Deep-Sea Res Part I Oceanogr Res Pap 46:1095-1099

Excoffier L, Smouse PE, Quattro JM (1992) Analysis of molecular variance inferred from metric distances among DNA haplotypes: application to human mitochondrial DNA restriction data. Genetics 131:479-491

Gage PA, Young CM (1999) Reproduction and dispersal at vents and cold seeps. J Mar Biol Assoc UK 79:193-208

Goochi JL, Schopf TJM (1972) Genetic variability in the deep sea: relation to environmental variability. Evolution 26: $545-552$

Gorbarenko SA, Southon JR (2000) Detailed Japan Sea paleoceanography during the last $25 \mathrm{kyr}$ : constraints from AMS dating and $\delta^{18} \mathrm{O}$ of planktonic foraminifera. Palaeogeogr Palaeoclimatol Palaeoecol 126:177-193

Jukes TH, Cantor CR (1969) Evolution of protein molecules. In: Munro HN (ed) Mammalian protein metabolism. Academic Press, New York, p 21-132

Kojima S, Segawa R, Hayashi I (1997) Genetic differentiation among populations of Japanese turban shell Turbo (Batillus) cornutus corresponding to warm currents. Mar Ecol Prog Ser 150:149-155

Kojima S, Segawa R, Hayashi I (2000) Stability of the courses of the warm currents along the Kyushu Island suggested by the population structure of the Japanese turban shell Turbo (Batillus) cornutus. J Oceanogr 56:601-604

Lee WL, Conroy J, Howell WH, Kocher TD (1995) Structure and evolution of teleost mitochondrial control regions. J Mol Evol 41:54-66

Magoulas A, Tsimenides N, Zouros E (1996) Mitochondrial DNA phylogeny and the reconstruction of the population history of a species: the case of the Europe anchovy (Engraulis encrasicolus). Mol Biol Evol 13:178-190

Matsuoka N, Kohyama K, Asano H (1995) Genetic distance and enzyme variation in local populations of two echinoderms from Japanese waters. Comp Biochem Physiol B 110:225-233

Murphy LS, Rowe GT, Haedrich RL (1976) Genetic variability in deep-sea echinoderms. Deep-Sea Res 23:339-348

Nakabo T (1993) Fishes of Japan with pictorial keys to the species. Tokai University Press, Tokyo

Nei M (1987) Molecular evolutionary genetics. Columbia University Press, New York 
Oba T, Kato M, Kitazato H, Koizumi I, Omura A, Sakai T, Takayama $T$ (1991) Palaeoenvironmental changes in the Japan Sea during the last 85, 000 years. Paleoceanography 6:499-518

Ohshima K (1990) The history of straits around Japanese Islands in the Late-Quaternary. Quat Res (Tokyo) 29: 193-208 (in Japanese with English abstract)

Palumbi S, Martin A, Romano S, McMillan WO, Stice L, Grabowski G (1991) The simple fool's guide to PCR, Version 2. Department of Zoology and Kewalo Marine Laboratory, University of Hawaii, Honolulu

Schnider S, Kueffer JM, Roessli D, Excoffer L (1996) Arlequin, a software package for population genetics. Genetics and Biometry Laboratory, Department of Anthropology, University of Geneva, Geneva

Soulé M (1976) Allozyme variation: its determinants in space and time. In: Ayala FJ (ed) Molecular evolution. Sinauer Associates, Sunderland, MA, p 60-77

Editorial responsibility: Otto Kinne (Editor), Oldendorf/Luhe, Germany
Tada R (1994) Paleoceanographic evolution of the Japan Sea. Palaeogeogr Palaeoclimatol Palaeoecol 108:487-508

Tada R, Irino T, Koizumi I (1999) Land-ocean linkages over orbital and millennial timescales recorded in late Quaternary sediments of the Japan Sea. Paleoceanography 14: 236-247

Tajima F (1983) Evolutionary relationship of DNA sequences in finite populations. Genetics 105:437-460

Tajima F, Nei M (1984) Estimation of evolutionary distance between nucleotide sequences. Mol Biol Evol 1:269-285

Tanimura Y (1981) Late Quaternary diatoms and paleoceanography of the Sea of Japan. Quat Res (Tokyo) 20:231-242 (in Japanese with English abstract)

Thuesen EV, Numachi K, Terazaki M (1993) Genetic variation in the planktonic chaetognaths Parasagitta elegans and Eukrohnia hamata. Mar Ecol Prog Ser 101:243-251

Valentine JW, Ayala FJ (1975) Genetic variation in Frieleia halli, a deep-sea brachiopod. Deep-Sea Res 22:37-44

Submitted: May 30, 2000; Accepted: December 8, 2000 Proofs received from author(s): July 12, 2001 